\title{
Arbeidsmarktindicatoren: een inventarisatie
}

\author{
Citation for published version (APA):
}

de Grip, A., \& Heijke, J. A. M. (1988). Arbeidsmarktindicatoren: een inventarisatie. Researchcentrum voor Onderwijs en Arbeidsmarkt, Faculteit der Economische Wetenschappen. ROA Working Papers No. 1 https://doi.org/10.26481/umarow.1988001

Document status and date:

Published: 01/01/1988

DOI:

10.26481/umarow.1988001

Document Version:

Publisher's PDF, also known as Version of record

\section{Please check the document version of this publication:}

- A submitted manuscript is the version of the article upon submission and before peer-review. There can be important differences between the submitted version and the official published version of record.

People interested in the research are advised to contact the author for the final version of the publication, or visit the DOI to the publisher's website.

- The final author version and the galley proof are versions of the publication after peer review.

- The final published version features the final layout of the paper including the volume, issue and page numbers.

Link to publication

\footnotetext{
General rights rights.

- You may freely distribute the URL identifying the publication in the public portal. please follow below link for the End User Agreement:

www.umlib.nl/taverne-license

Take down policy

If you believe that this document breaches copyright please contact us at:

repository@maastrichtuniversity.nl

providing details and we will investigate your claim.
}

Copyright and moral rights for the publications made accessible in the public portal are retained by the authors and/or other copyright owners and it is a condition of accessing publications that users recognise and abide by the legal requirements associated with these

- Users may download and print one copy of any publication from the public portal for the purpose of private study or research.

- You may not further distribute the material or use it for any profit-making activity or commercial gain

If the publication is distributed under the terms of Article $25 \mathrm{fa}$ of the Dutch Copyright Act, indicated by the "Taverne" license above, 


\section{ARBEIDSMARKTINDICATOREN:}

EEN INVENTARISATIE

ROA-W-1988/1

A. de Grip, J.A.M. Heijke

RESEARCHCENTRUM VOOR ONDERWIJS EN ARBEIDSMARKT

Faculteit der Economische Wetenschappen

Rijksuniversiteit Limburg

Maastricht, oktober 1988 
INHOUDSOPGAVE

Bladzijde

1. INLEIDING 1

2. ARBEIDSMARKTINDICATOREN 3

2.1. Indicator actuele arbeidsmarktschaarste 3

2.2. Vervangingsbehoefte en absorptiegraad beroepen 5

2.3. Conjunctuurgevoeligheid beroepen en opleidingen 6

2.4. Uitwijkmogelijkheden van beroepen en opleidingen 8

2.4.1. Spreidingsindicatoren 8

2.4.2. Passieve en actieve substitutie 12

2.4.3. Werkzaam buiten beoogde beroepsdomein 13

2.4.4. Verdringingsindicator $\quad 14$

2.5. Concurrentiekracht opleidingen 15

2.6. Toe- en uittredingsmobiliteit van beroepen 17

3. RELATIE ARBEIDSMARKTPROGNOSES EN INDICATOREN 19

3.1. Arbeidsmarktindicatoren als additionele kengetallen 19

3.2. Integratie arbeidsmarktprognoses en indicatoren 20

4. BESLUIT 24

$\begin{array}{ll}\text { LITERATUUR } & 27\end{array}$ 


\section{PNLEIDING}

In opdracht van het Ministerie van Onderwijs en Wetenschappen werkt het Researchcentrum voor Onderwijs en Arbeidsmarkt aan de ontwikkeling van een informatiesysteem onderwijs-arbeidsmarkt ten behoeve van de studieen beroepskeuzevoorlichting aan leerlingen en studenten in het voortgezet- en hoger onderwijs. Tevens kan dit informatiesysteem van nut zijn voor de capaciteitsplanning van de onderwijsvoorzieningen en het recruteringsbeleid van zowel het bedrijfsleven als overheidsinstanties (zie ook ROA 1986).

Prognoses van de arbeidsmarktperspectieven van beroepen en opleidingen vormen in feite het belangrijkste onderdeel van het informatiesysteem. Daarnaast bestaat er echter zowel binnen het werkveld van de studie- en beroepskeuzevoorlichting, als bij het recruteringsbeleid van arbeidsorganisaties eveneens een behoefte aan 'arbeidsmarktindicatoren' (De Grip, Heijke, Dekker, Groot en Vos 1987; Van Paridon 1987). Bij de studie- en beroepskeuzevoorlichting zijn prognoses immers vooral bedoeld om de kans op het vinden van een eerste baan na het afronden van een opleiding aan te geven. Daarnaast is het echter ook belangrijk om een indicatie te hebben van de latere mogelijkheden op de arbeidsmarkt en de risico's die men daarbij loopt. In De Grip, Heijke, Dekker en Groot (1987) wordt geprobeerd in deze behoefte te voorzien door middel van arbeidsmarktindicatoren met betrekking tot de conjunctuurgevoeligheid van de werkgelegenheid in de verschillende beroepsgroepen en de uitwijkmogelijkheden van opleidingen en beroepen naar andere beroepen en bedrijfstakken.

$\mathrm{Er}$ is echter ook behoefte aan arbeidsmarktindicatoren met betrekking tot de huidige arbeidsmarktsituatie. Voor werkgevers is dit bijvoorbeeld van belang in verband met hun wervingsinspanningen op de verschillende arbeidsmarktsegmenten. Dergelijke monitoring-indicatoren kunnen bovendien de richting aangeven, waarin relatief kortdurende omscholingsprojecten of andere arbeidsvoorzieningsmaatregelen zouden kunnen plaatsvinden. Maar ook met betrekking tot het reguliere onderwijsbeleid zijn arbeidsmarktindicatoren met betrekking tot de actuele arbeidsmarktsituatie van belang, bijvoorbeeld in verband met de toet- 
sing van een beleid gericht op het verbreden van het kwalificatieprofiel van een bepaalde opleiding. Op basis van monitoring-indicatoren kan dan binnen relatief korte tijd worden nagegaan in hoeverre een verbreding van de opleiding leidt tot een grotere spreiding van de afstuderenden over beroepen en/of bedrijfssectoren. Ook in het algemeen kunnen dergelijke flexibiliteitsindicatoren een goed beeld geven van het actuele functioneren van het onderwijs met betrekking tot de arbeidsmarkt.

Deze studie beoogt een eerste inventarisatie te geven van de verschillende soorten arbeidsmarktindicatoren die zouden kunnen worden geconstrueerd. Daarbij zal telkens allereerst worden ingegaan op de betekenis en de berekeningswijze van de indicator, waarna zal worden aangegeven welke functie de desbetreffende indicator zou kunnen hebben voor de studie- en beroepskeuzevoorlichting, de onderwijsplanning en het recruteringsbeleid van werkgevers. Tenslotte zal telkens een beeld worden geschetst van de beschikbaarheid van adequaat datamateriaal op basis waarvan de desbetreffende indicator zou kunnen worden berekend en zal een suggestie worden gedaan voor het verkrijgen van beter datamateriaal.

De inventarisatie van arbeidsmarktindicatoren is te vinden in het tweede hoofdstuk. Achtereenvolgens komen aan de orde een indicator met betrekking tot de actuele schaarste op de arbeidsmarkt (paragraaf 2.1), indicatoren met betrekking tot de vervangingsbehoefte en de absorptiegraad van beroepen (paragraaf 2.2), de conjunctuurgevoeligheid van beroepen en opleidingen (paragraaf 2.3 ), de uitwijkmogelijkheden voor beroepen en opleidingen (paragraaf 2.4 ), de concurrentiekracht van opleidingen (paragraaf 2.5) en de toe- en uittredingsmobiliteit in beroepen (paragraaf 2.6). Daarna zal in hoofdstuk 3 worden ingegaan op de relatie tussen arbeidsmarktprognoses en arbeidsmarktindicatoren. Op dit punt staat een tweetal mogelijkheden open. Het hanteren van arbeidsmarktindicatoren als afzonderlijke aanvullende kengetallen (paragraaf 3.1), of het combineren van arbeidsmarktprognoses en -indicatoren in voorspellingen van de arbeidsmarktsituatie van verschillende beroepsgroepen (paragraaf 3.2). In het slothoofdstuk worden enkele samenvattende opmerkingen gemaakt. 


\section{ARBEIDMARKTINDICATOREN}

\subsection{Indicator actuele arbeidsmarktschaarste}

Van Paridon (1987) heeft geprobeerd een monitoring-indicator te ontwikkelen met betrekking tot de actuele schaarste op de arbeidsmarkt van verschillende specifieke opleidingscategorieën. Deze indicator is een simpele omzetting van het werkioosheidspercentage onder de schoolverlaters van een bepaalde opleiding in een indicator, waarbij gecorrigeerd wordt voor de vervuiling van de geregistreerde werkloosheidsgegevens. Op basis van deze schaarste-indicator komt Van Paridon tot een typering van de arbeidsmarktsituatie met betrekking tot de onderscheiden studierichtingen. Daarbij wordt verondersteld dat de arbeidsmarkt van schoolverlaters in evenwicht is bij een geschoonde werkloosheid van 5 tot $7 \%$, hetgeen correspondeert met een geregistreerde werkloosheid van maar liefst $15 \%$. Tabel 1 laat zien hoe deze typeringen van de arbeidsmarktsituatie tot stand komen.

Tabel 1: Berekeningswijze schaarste-indicator en corresponderende typering van de arbeidsmarktsituatie

\begin{tabular}{|c|c|c|}
\hline $\begin{array}{c}\text { Gecorrigeerd } \\
\text { werkloosheidspercentage }\end{array}$ & Arbeidsmarktindicator & $\begin{array}{c}\text { Typering } \\
\text { arbeidsmarktsituatie }\end{array}$ \\
\hline $\begin{array}{l}0-3 \% \\
3-5 \% \\
5-7 \% \\
7-9 \% \\
>9 \%\end{array}$ & $\begin{array}{r}0-50 \\
51-83 \\
84-117 \\
118-150 \\
>150\end{array}$ & $\begin{array}{l}\text { groot tekort } \\
\text { tekort } \\
\text { evenwicht } \\
\text { overschot } \\
\text { groot overschot }\end{array}$ \\
\hline
\end{tabular}

Deze arbeidsmarktindicator is ontwikkeld vanuit de behoefte van het bedrijfsleven aan een monitoring-indicator met betrekking tot de ontwikkeling van de arbeidsmarktsituatie van opleidingscategorieën waarvoor problemen worden geconstateerd bij de personeelswerving. De keuze van de werkloze schoolverlaters is ongetwijfeld vooral het gevolg van het feit dat voor deze groep een werkloosheidspercentage kan worden geconstrueerd op basis van de snel beschikbare onderwijsuitstroomgegevens in plaats van de gegevens van de beroepsbevolking die tot nu toe 
slechts een keer in de twee jaar op steekproefbasis en met grote vertraging beschikbaar komen. De indicator sluit ook goed aan bij het recruteringsgedrag van met name grote bedrijven die over een zogenaamde 'interne arbeidsmarkt' beschikken (Van Bergeijk \& De Grip 1986). Immers, schoolverlaters vormen de belangrijkste doelgroep in het wervingsbeleid op dergelijke interne arbeidsmarkten.

De keuze van een gecorrigeerd werkloosheidspercentage van $5-7 \%$ als matstaf voor een evenwichtige arbeidsmarkt is arbitrair en is vanuit het oogpunt van onderwijsplanning en studiekeuzevoorlichting zonder meer aan de hoge kant. Het werkloosheidspercentage dat men als evenwichtig ervaart, kan overigens voor individuele bedrijven sterk uiteenlopen. Van belang hierbij is de marktpositie die het bedrijf op een arbeidsmarktsegment inneemt. Zo zullen bedrijven met een grote aantrekkingskracht onder schoolverlaters zelfs bijeen laag werkloosheidspercentage nog vrij gemakkelijk nieuwe arbeidskrachten kunnen aantrekken. Daarentegen zullen bedrijven met een geringer appeal zelfs bij een gecorrigeerd werkloosheidspercentage van $7 \%$ nog moeilijkheden ondervinden, indien schoolverlaters liever enige tijd werkloos blijven dan bij het desbetreffende bedrijf te gaan werken, in de hoop op een baan bij een bedrijf waarvan men verwacht dat de loopbaanperspectieven beter zijn.

Desalniettemin kan geconcludeerd worden dat deze actuele-schaarsteindicator bruikbaar is als monitoring-indicator van de situatie op de arbeidsmarkt. Waarbij een nadere empirische analyse antwoord zal moeten geven op de vraag bij welk (gecorrigeerd) werkloosheidspercentage men kan spreken van een evenwichtssituatie op het desbetreffende arbeidsmarktsegment.

De schaarste-indicator kan momenteel worden berekend op basis van gedetailleerde informatie met betrekking tot de officieel geregistreerde werkloosheid (ISVA-bestand) en de CPB schoolverlatersprognoses, die verder kunnen worden verbijzonderd met behulp van gediplomeerden-cijfers uit diverse CBS-onderwijsstatistieken. Gezien het slechts indicatieve karakter van deze schaarstemaatstaf is de behoefte aan kwalitatief beter datamateriaal hier niet groot, al zou het direct beschikbaar zijn van geschoonde werkloosheidscijfers een kwaliteitsverbetering van de indicator betekenen. 


\subsection{Vervangingsbehoefte en absorptiegraad beroepen}

Door De Grip, Heijke en Vos (1987) zijn twee indicatoren ontwikkeld met betrekking tot de relatieve vervangingsbehoefte (RVB) in beroepen en de mate waarin jongeren werk hebben gevonden in deze beroepen de zogenaamde 'absorptiegraad' (RAG). Deze maatstaven zijn daarbij als volgt berekend:

(1) $\mathrm{RVB}_{\mathbf{i}}=\%$ aandeel $50-64$ jarigen in beroep $\mathbf{i}$ $\%$ aandeel 50-64 jarigen in totale werkzame bevolking

(2) $R A G_{j}=\%$ aandee $1<30$ jarigen in beroep $i$ $\%$ aandeel $<30$ jarigen in totale werkzame bevolking

Voor deze maatstaven geldt dat een waarde >1 duidt op een grote relatieve vervangingsbehoefte, respectievelijk een grote relatieve absorptie van jongeren in het desbetreffende beroep. Bij beide vindt overigens nog een correctie plaats om te voorkomen dat een vertekend beeld wordt gegeven. Zo kan de RVB tot een overschatting leiden van de te verwachten vervangingsvraag in een beroepsgroep, waar de werkgelegenheidsgroei reeds geruime tijd stagneert. In dat geval moet immers betwijfeld worden of uittredende oudere arbeidskrachten daadwerkelijk door jongeren zullen worden vervangen. Om een dergelijke vertekening te voorkomen wordt de RVB-indicator gewogen met het indexcijfer van de relatieve werkgelegenheidsontwikkeling gedurende de voorafgaande 10 jaar (De Grip, Heijke en Vos (1987).

Bij de RAG-indicator is een correctie nodig vanwege het feit dat de leeftijdsgroep < 30 jaar meer cohorten schoolverlaters omvat van de lagere dan van de hogere opleidingsniveaus. Als gevolg daarvan kan de absorptiegraad van beroepen warin relatief veel hoger opgeleide werkzaam zijn worden onderschat. Dit leidde tot de volgende correctiefactoren: 14/12 (van het aandeel HAVO/VWO-ers) 14/11 (van het aandeel MBOers), 14/8 (van het aandeel HBO-ers) en $14 / 6$ (van het aandeel W0-ers) (zie De Grip, Heijke en Vos $(1987)^{1}$.

1. De correctiefactoren zijn gebaseerd op het verschil tussen de modale leeftijd waarop men op het desbetreffende opleidingsniveau de school verlaat en de 16-jarige leeftijd (einde leerplicht). Daarbij is telkens een vergelijking gemaakt met de bovengrens van het geanalyseerde cohort ( 30 jaar). 
De RVB-maatstaf is bedoeld als een eerste indicator van de vervangingsbehoefte van de verschillende beroepen. Deze informatie is van belang voor zowel de studie- en beroepskeuzevoorlichting, de onderwijsplanning als het wervingsbeleid van werkgevers. Het heeft echter weinig zin een dergelijke indicator op basis van gegevens uit het verleden te construeren, wanneer er ook mogelijkheden zijn om prognoses van de toekomstige vervangingsvraag op te stellen in het kader van de ROAprognoses van de arbeidsmarktontwikkeling op de middellange termijn (zie De Grip, Heijke, Dekker en Groot, 1987).

Daarentegen is de RAG wel een bruikbare maatstaf, omdat op basis hiervan kan worden vastgesteld welke beroepen als typische intredeberoepen op de arbeidsmarkt kunnen worden beschouwd. Deze informatie is zowel van belang voor de studie-en beroepskeuzevoorlichting als voor een onderwijsbeleid dat is gericht op het verbeteren van de aansluiting van het onderwijs op de intredebanen, die een belangrijke schakel kunnen vormen met betrekking tot de latere beroepsloopbaan.

Beide matstaven kunnen momenteel worden berekend op basis van de CBSArbeidskrachtentellingen. Verwacht mag worden dat op basis van de Enquête Beroepsbevolking soortgelijke indicatoren kunnen worden berekend. Daarbij zou in de toekomst een belangrijke kwaliteitsverbetering kunnen optreden, wanneer de door het CBS gehanteerde beroepenclassificatie beter aansluit bij het feitelijk functioneren van de arbeidsmarkt. Momenteel wordt hiertoe door het CBS een aanzet gegeven (Jonker, 1987).

\subsection{Conjunctuurgevoeligheid beroepen en opleidingen}

Ter aanvulling van de middellange-termijnprognoses, die een indicatie geven van de werkgelegenheidsperspectieven op het moment dat degenen die momenteel aan een studie beginnen op zoek gaan naar een baan, is door De Grip, Heijke, Dekker en Groot, (1987) geprobeerd informatie te geven over de mate van werkzekerheid in een beroep als gevolg van conjuncturele fluctuaties van de werkgelegenheid. Met het oog hierop is voor iedere bedrijfstak de volgende fluctuatie-index geconstrueerd: 
(3)

$$
F I_{j}=\frac{100}{H} \sum_{t=1}^{H} \frac{\left|F_{j t}\right|}{T_{j t}}
$$

Waarbij: $F I_{j}=$ fluctuatie-index bedrijfstak $j$

$H=$ aantal waarnemingsjaren

$t=$ jaar

$F_{j t}=$ afwijking van de werkgelegenheid van de trendmatige werkgelegenheidsontwikkeling in bedrijfstak $j$ op tijdstip $t$

$T_{j t}=$ trendmatige werkgelegenheidsontwikkeling bedrijfstak $j$ op tijdstip $t$

Op basis van de veronderstelling dat de werkgelegenheid van de verschillende beroepen binnen een bedrijfstak in gelijke mate fluctueert (een overigens niet geheel terechte veronderstelling, zie Dekker, De Grip en Heijke 1988), kan een fluctuatie-index worden afgeleid van de verschillende beroepen, door de fluctuatie-indices van de verschillende bedrijfstakken te wegen met het aandeel van een beroep in de werkgelegenheid van de desbetreffende bedrijfstak:

(4) $C G_{j}=\sum_{j=1}^{J} \frac{E_{i j}}{E_{j}} \quad F I_{j}=\sum_{j=1}^{J} a_{i j} F I_{j}$

Waarbij: $C_{i}=$ indicator conjunctuurgevoeligheid beroepsklasse $i$

$E_{i j}=$ aantal werkenden in beroep $i$ werkzaam in bedrijfstak $j$

$E_{j}=$ totaal aantal werkenden in beroep $i$

$\begin{aligned} \alpha_{i j} & =\text { aandeel beroep } i \text { werkzaam in bedrijfstak } j \\ & =\text { aantal bedrijfstakken }\end{aligned}$

Op soortgelijke wijze kan een indicator worden berekend voor de conjunctuurgevoeligheid van de werkgelegenheid van de verschillende opleidingscategorieën. Hierbij moet (waarschijnlijk eveneens niet geheel terecht) worden verondersteld dat de werkgelegenheid van de verschillende opleidingscategorieën binnen een bedrijfstak in gelijke mate fluctueert. De berekeningswijze is dan als volgt:

(5) $C G_{k}=\sum_{j=1}^{J} \frac{E_{k j}}{E_{k}}=\sum_{j=1}^{J} \beta_{k j} F_{j}$

Waarbij: $\mathrm{CG}_{k}=$ indicator conjunctuurgevoeligheid opleiding $k$

$E_{k j}=$ aantal werkenden met opleiding $k$ werkzaam in bedrijfstak j

$E_{k}=$ totaal aantal werkenden met opleiding $k$

$\beta_{k j}=$ aandeel opleiding $k$ in werkzaam in bedrijfstak $j$ 
Op basis van de gemiddelde waarde van de conjunctuurindicator kan de mate van conjuntuurgevoeligheid van beroepen en opleidingen worden getypeerd. De Grip, Heijke, Dekker en Groot (1987) doen dit aan de hand van een 5-punts schaal.

Een zwak punt van deze indicator is zoals gezegd dat, vanwege het vooralsnog ontbreken van werkgelegenheidscijfers naar beroep en opleiding over een langere periode, de veronderstelling moet worden gemaakt dat de conjunctuurschommelingen van beroepen- en opleidingscategorieën binnen een bedrijfstak gelijkmatig verlopen.

Beide conjunctuurindicatoren zijn vooral van belang voor de studie- en beroepskeuzevoorlichting. Ze zijn eveneens van nut voor het arbeidsvoorzienings- c.q. omscholingsbeleid en voor het reguliere onderwijsplanningsbeleid, in de zin dat in geval van tekorten of overschotten aan arbeidskrachten in sterk conjunctuurgevoelige beroepen en opleidingscategorieën er rekening zou kunnen gehouden worden met het mogelijk tijdelijke karakter van deze tekorten of overschotten. Vanzelfsprekend is het voor een evenwichtig oordeel op dit punt nodig om de conjunctuurgevoeligheidsindicator in verband te brengen met de middellange-termijnprognoses van de onwikkeling op de arbeidsmarkt.

Het datamateriaal dat momenteel kan worden gebruikt voor het berekenen van conjunctuurgevoeligheidsindicatoren bestaat voor wat betreft de werkgelegenheidsontwikkeling naar bedrijfstak uit arbeidsvolumegegevens uit de Nationale Rekeningen. De aandelen van beroepen en opleidingen in de werkgelegenheid in de verschillende bedrijfstakken kunnen worden verkregen met behulp van gegevens uit de Arbeidskrachtentelingen en voor wat de toekomstige ontwikkeling betreft uit de cijfers van de middellange-termijnprognoses.

\subsection{Uitwijkmogelijkheden van beroepen en opleidingen}

\subsubsection{Spreidingsindicatoren}

Van Hoof en Dronkers (1980) bekritiseren de vaak geuite opvatting dat er een exclusieve relatie bestaat tussen een bepaalde opleiding en een bepaald beroep. Deze door hen als het 'naĩeve model' van de arbeids- 
markt getypeerde visie, negeert ten onrechte de bestaande flexibiliteit in de aansluiting tussen opleidingen en beroepen. Van Hoof en Dronkers bepleiten vanuit het oogpunt van een betere werking van de arbeidsmarkt dat het beleid meer gericht wordt op het vergroten van deze flexibiliteit door het verbreden van het kwalificatieprofiel van de diverse opleidingen (zie ook De Grip, 1987).

Door Warncken $(1986)^{2}$ is een maatstaf ontwikkelt die een indicatie geeft van de bestaande flexibiliteit op de arbeidsmarkt: De 'GiniHirschman coëfficiënt. Door de Grip, Heijke, Dekker en Groot (1987) is op basis van deze coëfficiënt een indicatie gegeven van de spreiding van de beroepen over de verschillende bedrijfstakken. De berekeningswijze van de branchespreidingsindicator van beroepen is als volgt:

(6) $\operatorname{SBBR}_{i}=\left(1-\sum_{j=1}^{J} \alpha_{i j}{ }^{2}\right) \frac{J}{J-1}$

Waarbij: SBBR $_{\mathbf{j}}=$ Gini-Hirshman coëfficiënt branchespreiding van beroep i

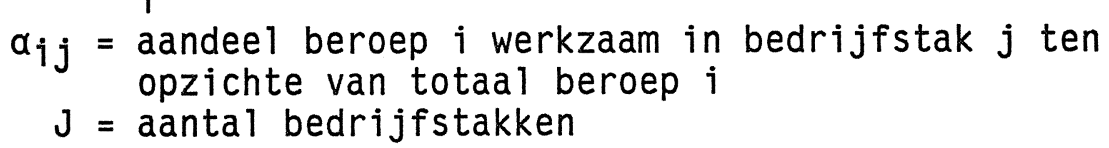

Deze indicator kan waarden aannemen tussen 0 en 1 . De indicator is 0 als het beroep in slechts één branche voorkomt en 1 als hij gelijkmatig over alle branches is gespreid.

Op soortgelijke wijze berekenen De Grip, Heijke, Dekker en Groot een indicator van de beroepenspreiding van de verschillende opleidingscategorieën:

2. Sheldon (1985) vermeldt een tweetal alternatieve specificaties van dergelijke flexibiliteitsindicatoren. De indicator van Kraft cs. heeft als nadeel dat de waarde van de matstaf afhankelijk is van het aantal onderscheiden 'adequaat bezette' cellen in de te analyseren rij of kolom van bijvoorbeeld een opleidingenberoepenmatrix. Het is echter onduidelijk wat onder 'adequaat bezet' moet worden verstaan. De indicator van Heimer \& Weisshuhn biedt daarentegen wel een alternatieve specificatiemogelijkheid:

(6b) $\operatorname{SBBR}_{i}=\left(\sum_{j=1}^{J} \alpha_{i j}{ }^{2}\right)^{-1}-1$ 
(7) $\left.\mathrm{SOB}_{k}=\left(1-\sum_{i=1}^{I} \gamma_{k i}{ }^{2}\right)\right) \frac{I}{I-1}$

Waarbij: $\mathrm{SOB}_{k}=$ Gini-Hirshman coëfficiënt beroepenspreiding van opleiding $k$

$\gamma_{k i}=$ aandeel opleiding $k$ werkzaam in beroep $i$, in totaal aantal arbeidskrachten met opleiding $k$ $\left(\gamma_{k j}=E_{k j} / E_{k}\right)$

$I$ = aantal beroepen.

Ook bestaat de mogelijkheid een dergelijke indicator te berekenen van de branchespreiding van opleidingen:

(8) $\operatorname{SOBR}_{k}=\left(1-\sum_{j=1}^{J} \beta_{k j}{ }^{2}\right) \frac{J}{J-1}$

Waarbij: SOBR $_{k}=$ Gini-Hirschman coëfficiënt branchespreiding van opleiding $k$

$\beta_{k j}=$ aandeel opleiding $k$ werkzaam in bedrijfstak $j$

$\left(\beta_{k j}=E_{k j} / E_{k}\right)$

$\mathrm{J}=$ aantal bearijfstakken

Hetzelfde geldt voor de opleidingsspreiding van beroepen:

(9) $\mathrm{SBO}_{i}=\left(1-\sum_{\mathrm{k}=1}^{\mathrm{K}} \theta_{\mathrm{k} i}{ }^{2}\right) \frac{\mathrm{K}}{\mathrm{K}-1}$

Waarbij: $\mathrm{SBO}_{j}=$ Gini-Hirschman coëfficiënt opleidingspreiding beroep $i$

$\theta_{k j}=$ aandee 1 van werkenden in beroep $i$ met opleiding $k$ $\left(\theta_{k j}=E_{k j} / E_{j}\right)$

$K=$ aantal opleidingen

Bij bovenstaande indicatoren wordt gecorrigeerd voor het aantal onderscheiden bedrijfstakken beroepen en opleidingen door respectievelijk de correctietermen $\mathrm{J} / \mathrm{J}-1$, I/I-1 en $\mathrm{K} / \mathrm{K}-1$. Op deze wijze wordt gecorrigeerd voor het gekozen aggregatieniveau.

Voor een typering van de mate van arbeidsmarktflexibiliteit is men genoodzaakt enigszins arbritaire scheidslijnen te trekken ${ }^{3}$.

3. (zie ook Warnken (1986) en De Grip, Heijke, Dekker, Groot (1987)). 

$\mathrm{GH}=0$
geen enkele spreiding/flexibiliteit/uitwijkmoge- lijkheden ( het ideaaltypische naieve model)
$0<\mathrm{GH} \leq 0,3$
geringe spreiding/flexibiliteit; weinig uitwijk- mogelijkheden
$0,3<\mathrm{GH} \leq 0,7$
gemiddelde spreiding; enige flexibiliteit/uitwijk- mogelijkheden
$0,7<\mathrm{GH}<1,0$
grote spreiding/flexibiliteit; veel uitwijkmoge- lijkheden
$\mathrm{GH}=1$
geheel gelijkmatige spreiding; algehele flexibili- teit; onbeperkte uitwijkmogelijkheden (het ideaal- typische flexibiliteitsmodel)

De hier gepresenteerde flexibiliteitsindicatoren kunnen van groot belang zijn voor de studie- en beroepskeuzevoorlichting. Zij kunnen additionele informatie bieden ten opzichte van de middellange termijnprognoses van de arbeidsmarktperspectieven van beroepen en opleidingen en de conjunctuurgevoeligheidsindicatoren. Ze geven daarbij een indicatie van de uitwijkmogelijkheden die iemand heeft, wanneer men kiest voor een bepaalde opleiding of voor een bepaald beroep. Dit is vanzelfsprekend vooral van belang wanneer de arbeidsmarkt voor de gekozen opleiding of het beroep zich op een bepaald moment ongunstig ontwikkelt.

Daarnaast geeft de indicator van de opleidingspreiding van een beroep een indruk van de concurrentie tussen de verschillende opleidingen met betrekking tot de uitoefening van dit beroep. Maar ook los van de ontwikkelingen op de arbeidsmarkt hebben deze flexibiliteitsindicatoren hun waarde bij de studie- en beroepskeuzevoorlichting, in die zin dat zij een indruk geven van de mate waarin men zich met de keuze van een studie of beroep vastlegt voor een specifieke beroepsloopbaan.

De spreidingsindicatoren kunnen ook van belang zijn voor het onderwijsbeleid. Zo bieden ze de mogelijkheid om te toetsen of een verbreding van het kwalificatieprofiel van een bepalde opleiding inderdaad leidt tot een grotere flexibiliteit van de schoolverlaters op de arbeidsmarkt. Hetzelfde geldt natuurlijk voor omscholing in het kader van het arbeidsmarktbeleid.

Voor het recruteringsbeleid van werkgevers zou vooral de indicator van de opleidingsspreiding van beroepen van belang kunnen zijn, met name 
wanneer men geconfronteerd wordt met knelpunten op een bepaald arbeids marktsegment. In dat geval zou wel aanvullende informatie moeten worden verschaft over de opleidingscategorieën, waarnaar men bij het wervingsbeleid dan zou kunnen uitwijken.

Bovenstaande indicatoren kunnen momenteel alleen over de volle breedte van de arbeidsmarkt worden berekend voor de in de Arbeidskrachtentellingen onderscheiden beroepsgroepen en opleidingscategorieën. Voor de meeste beleidsdoelen is deze informatie te weinig specifiek. Een grote verbetering zou op dit punt kunnen worden gerealiseerd op basis van de RUBS-schoolverlatersenquêtes, die zijn voorgesteld door enkele Contactcentra Onderwijs Arbeidsmarkt ( $\left.O A^{\prime} s\right)$ en de Landelijke Commissie Academische Studiekeuzevoorlichting (LCAS). Niet alleen zou men met deze gegevens indicatoren kunnen berekenen van veel specifiekere opleidingscategorieën, maar er zouden op den duur ook leeftijd-, of cohortspecifieke spreidingsindicatoren kunnen worden berekend.

\subsubsection{Passieve en actieve substitutie}

De rijen van de matrix van werkenden naar opleiding en naar beroep geven informatie over de opleidingen die voor een beroep opleiden. Sheldon (1985) veronderstelt dat iedere opleiding een hoofdberoep kent. Het percentage van de werkgelegenheid in dat hoofdberoep dat de overige opleidingscategorieën innemen, kan dan geĩnterpreteerd worden als de passieve substitutie, dat wil zeggen de uitstotingsgraad van de opleiding waarvoor het desbetreffende beroep het hoofdberoep is:

$$
P S_{k}=1-\frac{E_{k b}}{E_{b}}=1-\theta_{k b}
$$

Waarbij $P S_{k}=$ passieve substitutiegraad opleiding $k$

$E_{k b}=$ aantal werkenden in hoofdberoep $b$ met opleiding $k$

$\mathrm{E}_{\mathrm{b}}=$ aantal werkenden in beroep $\mathrm{b}$

Het is echter de vraag of de meeste opleidingscategorieën wel een hoofdberoep kennen en of een bepaald beroep niet voor meer dan één opleiding het hoofdberoep is. Daarom is het waarschijnijjk voor veel beroepen reëler om vast te stellen hoeveel opleidingscategorieën, ge- 
rangschikt in volgorde van afnemende grootte, tezamen bijvoorbeeld $80 \%$ van het aantal werkenden in het beroep omvatten. Op deze manier krijgen we een vrij directe matstaf voor de flexibiliteitsmogelijkheden voor werkgevers bij de recrutering van personeel voor een bepaald beroep.

In feite beogen bovenstaande matstaven soortgelijke informatie te verstrekken als de opleidingsspreidingsindicator $\mathrm{SBO}_{j}$ (vergelijking 9). De extra informatie die daarbij wordt gegeven is echter gering. Voor het recruteringsbeleid van werkgevers is het waarschijnlijk zinvoller om meer specifieke informatie te verstrekken over de opleidingsachtergronden van de werkenden in een bepaald beroep.

Naast de 'passieve substitutie' van een bepaalde opleiding uit het hoofdberoep, onderscheidt Sheldon ook de actieve substitutie van een opleiding, in de zin van de uitwijkmogelijkheden naar andere beroepen:

(11) $A S_{k}=1-\frac{E_{k b}}{E_{k}}=1-\gamma_{k b}$ Waarbij: $A S_{k}=$ actieve substitutiegraad opleiding $k$

$E_{k b}=$ aantal werkenden in hoofdberoep $b$ met opleiding $k$

$E_{k}=$ aantal werkenden met opleiding $k$

Hier geldt opnieuw het bezwaar dat er voor veel opleidingen niet éen enkel hoofdberoep bestaat. Een indicator van de flexibiliteitsmogelijkheden zou ook hier kunnen worden verkregen door vast te stellen in hoeveel beroepen, gerangschikt in volgorde van afnemende grootte, tezamen bijvoorbeeld $80 \%$ van het aantal opgeleiden werkzaam is. Hiermee wordt dezelfde informatie beoogd als met de flexibiliteitsindicator SOB $_{k}$ (vergelijking 7). Ten aanzien van de beschikbaarheid van de data die nodig zijn voor de berekening van bovenstaande indicatoren kan eveneens worden verwezen naar paragraaf 2.4.1.

\subsubsection{Werkzaam buiten beoogde beroepsdome in}

Wanneer voor een bepalde opleiding op basis van opvattingen van deskundigen kan worden bepaald welke beroepscategorieën tot het beroepsdomein van een opleiding gerekend kunnen worden, kan op basis van de 
beroepenstructuur van de afgestudeerden worden vastgesteld welk deel 'buiten de eigen sector' werkzaam is:

(12) $B S_{k}=1-\left(\sum_{i \in I} \gamma_{k i}\right)$

Waarbij: $\mathrm{BS}_{\mathrm{k}}=$ indicator aandeel werkenden buiten beoogde beroepsdomein van opleiding $k$

$I^{\prime}$ = verzameling van beroepen die gerekend worden tot het beroepsdomein van opleiding $k$

Deze matstaf zou een indicatie kunnen geven van de uitwijkmogelijkheden naar beroepsdomeinen die niet tot de eigen sector worden gerekend. Dit kan beschouwd worden als een specifieke vorm van aktieve substitutie. Een zwak punt van deze maatstaf is de waarschijniijk bij veel opleidingen arbitraire afbakening van het beoogde beroepsdomein van de desbetreffende opleiding.

De informatie is vooral belangrijk als performance-indicator van verschillende opleidingen, hetgeen van belang kan zijn voor zowel het onderwijs-als het studie- en beroepskeuzevoorlichtingsbeleid. Het probleem daarbij is echter dat moeilijk a priori gezegd kan worden of de gevonden uitwijkmogelijkheden naar andere sectoren positief of negatief moeten worden beoordeeld. Dit laatste zal vooral het geval zijn wanneer uitgeweken wordt naar beroepen waarvoor een lagere opleiding vereist is (neerwaartse verdringing). De hier voorgestelde indicator zal alleen berekend kunnen worden wanneer van een specifieke opleiding vast staat wat tot het beoogde beroepsdome in moet worden gerekend. Afgestudeerdenenquêtes zouden vervolgens geschikte data kunnen opleveren op basis waarvan de indicator kan worden vastgesteld.

\subsubsection{Verdringingsindicator}

Wanneer beroepen naar functieniveau getypeerd kunnen worden, zou voor de verschillende opleidingen kunnen worden vastgesteld in hoeverre het uitwijken naar niet met de opleiding beoogde beroepen als neerwaartse verdringing moet worden beschouwd. Deze verdringings- of onderbenuttingsindicator kan als volgt worden berekend: 
(13) $V I_{k}=\sum_{i \in I *} \frac{E_{k i}}{E_{k}}=\sum_{i \in I^{*}} \gamma_{k i}\left(I^{*} \subset I\right)$

Waarbij: $V I_{k}=$ verdringingsindicator opleiding $k$

$I^{*}=$ verzameling van beroepen waarvan het functieniveau lager is dan het met het opleidingsniveau corresponderende functieniveau.

Het typeren van het functieniveau van beroepen is bepaald niet zonder problemen. Bovendien moet een dergelijke typering periodiek wordt geactualiseerd. Tenslotte zou op basis van empirisch onderzoek een schaling moeten worden gemaakt aan de hand waarvan de onderbenuttingsgraad van de afgestudeerden van een bepaalde opleiding kan worden getypeerd.

De verdringingsindicator is van belang voor het monitoren van het allocatieproces op de arbeidsmarkt, ten behoeve van zowe 1 het onderwijsbeleid als het arbeidsmarktbeleid. Omdat de indicator aangeeft hoe groot de kans is dat men met de opleiding in functies terecht komt waarvoor in feite slechts een lagere opleiding vereist is, kan deze indicator ook van nut zijn voor de studie- en beroepskeuzevoorlichting. De verdringingsfactor zou hier kunnen worden gebruikt in aanvuliing op de middellange-termijn prognoses van de kans op werk die men met een bepaalde opleiding heeft.

In het verleden heeft het CBS de beroepen (op 4-digitniveau) binnen haar beroepenclassificatie getypeerd naar functieniveau (zie Huijgen, Riesewijk en Conen 1983). Helaas is het vanwege de ontoereikende omvang van de Arbeidskrachtentellingen niet mogelijk de opleidingsstructuur van beroepen op dit lage aggregatieniveau te bepalen. Ook hiervoor zouden schoolverlatersenquêtes een belangrijke aanvullende databron kunnen vormen.

\subsection{Concurrentiekracht opleidingen}

Haanstra, Koppen en Oostwoud Wijdenes (1987) suggereren een indicator voor de mate warin opleidingen in bepalde beroepen concurrentie ondervinden van andere opleidingen door te kijken naar het aandeel van de ingeschreven werklozen in een beroep dat de desbetreffende opleiding heeft genoten: 
(14) $\mathrm{CO}_{\mathrm{ki}}(1)=\frac{U_{k i}}{U_{i}}$

Waarbij: $\mathrm{CO}_{k i}(1)=$ concurrentiekracht opleiding $k$ in beroep $i$

$U_{k j}=$ aantal werklozen in beroep $i$ met opleiding $k$

$U_{j}=$ total aantal werklozen in beroep $i$

Een tweede mogelijkheid is te kijken naar het aandeel van de werkenden in een bepaald beroep dat de desbetreffende opleiding heeft gevolgd:

$$
C 0_{k i}(2)=\frac{E_{k i}}{E_{j}}=\theta_{k i}
$$

Voor een bepaalde opleiding kan op deze wijze voor alle beroepen de concurrentiekracht van de desbetreffende opleiding worden bepaald. Op basis van empirisch onderzoek zouden de grenzen tussen de verschillende typeringen (goed, redeljk, slecht) kunnen worden bepaald.

De eerste indicator heeft als nadeel dat een hoog aandeel van een opleiding in de werkloosheid in een bepald beroep niet eenduidig kan worden geĩnterpreteerd. Haanstra, Koppen en Oostwoud Wijdenes (1987) veronderstellen dat een hoog aandeel impliceert dat er weinig concurrentie is met anders opgeleide werklozen, zodat van een goede concurrentiepositie kan worden gesproken. Een hoog aandeel in de werkloosheid kan echter ook betekenen dat juist degenen met de desbetreffende opleiding minder snel in het beroep aan het werk komen dan anders opgeleiden. Met het oog daarop moet deze indicator als ongeschikt worden beoordeeld.

Dit probleem doet zich niet voor bij de tweede indicator; hier is het terecht een groot aandeel in de werkgelegenheid te interpreteren als een goede concurrentiepositie van de desbetreffende opleidingscategorie. Deze maatstaf is echter gebaseerd op arbeidskrachten die in het verleden met hun opleiding in het desbetreffende beroep werk vonden. Het is de vraag of dit ook lukt voor degenen die momenteel met dezelfde opleiding instromen op de arbeidsmarkt. Daarom is het wellicht beter om te kijken naar de ontwikkeling van het aandeel van een opleidingscategorie in een beroep. De maatstaf wordt dan: 
(16) $\mathrm{CO}_{\mathrm{ki}}(3)=\Delta \theta_{\mathrm{ki}}$

Waarbij: $\Delta \theta_{k j}=$ mutatie in de tijd van het aandeel van werkenden in beroep i met opleiding $k$

De concurrentiekracht van een opleiding in een beroep kan dan als volgt worden getypeerd:

$$
\begin{array}{ll}
\mathrm{CO}_{\mathrm{ki}}(3)>0 & \text { goede/verbeterde concurrentiepositie } \\
\mathrm{CO}_{\mathrm{ki}}(3)=0 & \text { stabiele concurrentiepositie } \\
\mathrm{CO}_{\mathrm{ki}}(3)<0 & \text { slechte/verslechterde concurrentie- } \\
& \text { positie }
\end{array}
$$

De indicator $\mathrm{CO}_{\mathrm{ki}}$ (3) heeft vooralsnog de voorkeur bij het typeren van de concurrentiekracht van een opleiding op de verschillende beroepsdeelmarkten. De indicator is beroepsspecifiek en zal daarom voor elke beroepscategorie afzonderlijk moeten worden berekend.

Het typeren van de concurrentiekracht van een opleiding op een beroepsdeelmarkt is vanzelfsprekend van belang voor de studie- en beroepskeuzevoorlichting. Tevens geeft het voor het onderwijs- en omscholingsbeleid een indicatie van de performance van studierichtingen, c.q. onderwijsinstellingen. Het is daarbij zinvol telkens de concurrerende opleidingen te noemen.

Momenteel kunnen bovenstaande indicatoren voor globale beroepscategorieën en clusters van studierichtingen worden berekend aan de hand van de gegevens van de Arbeidskrachtentellingen van het CBS. Het beschikbaar komen van meer gedetailleerd cijfermateriaal uit afgestudeerdenenquêtes zou het mogelijk maken de concurrentiekracht van meer specifieke studierichtingen - eventueel op meer specifieke werkterreinen in beeld te brengen.

\subsection{Toe- en uittredingsmobiliteit van beroepen}

Sheldon (1985) heeft de toe- en uittredingsmobiliteit van beroepen over een bepaalde tijdsperiode op basis van beroepsmobiliteitsgegevens vastgesteld. Uitgaande van een matrix met verticaal het aantal werkenden in de verschillende beroepen op tijdstip t-s en horizontaal dezelfde gegevens op tijdstip $t$, kan voor ieder beroep de toe- en uittredingsmobi- 
liteit in het tijdvak $t-s$ tot $t$ worden vastgesteld. De gegevens hebben alleen betrekking op arbeidskrachten die zowel op tijdstip t-s als op tijdstip t werkzaam waren.

De toetredingsmobiliteit naar beroep $i$ kan dan als volgt worden vastgesteld: $n_{. j}-n_{j}$. Wanneer de absolute aantallen worden omgezet in een indicator voor de relatieve toetredingsmobiliteit, krijgt men:

(17) $T M_{j}=n_{. j}-n_{i j}$

$$
\mathrm{n}_{\mathrm{i}}
$$

Waarbij: $\mathrm{TM}_{j}=$ indicator toetredingsmobiliteit beroep $i$

$n_{i j}=$ aantal arbeidskrachten dat in beroep $i j$ werkzaam is gebleven

$n_{i} j=$ arbeidskrachten werkzaam in beroep $i$ op moment $t$

$n_{i_{0}}=$ arbeidskrachten werkzaam in beroep $i$ op moment $t-s$

Volgens hetzelfde principe kan een maatstaf worden geconstrueerd voor de uittredingsmobiliteit $\left(U M_{j}\right)$ van beroep $i$ :

(18) $\quad \mathrm{UM}_{\mathbf{j}}=\mathrm{n}_{\mathbf{i}},-\mathrm{n}_{\mathbf{i}}$

$$
n_{i}
$$

In combinatie met elkaar kan de netto-mobiliteit $\left(\mathrm{NM}_{j}\right)$ van beroep $i$ worden vastgesteld:

(19) $N M_{j}=T M_{j}-U M_{j}$

Bovenstaande indicatoren geven een indruk van respectievelijk de mate waarin toetreders tot een beroep uit andere beroepscategorieën afkomstig zijn, de mate waarin de werkenden in een beroep doorstromen naar andere beroepen en tenslotte de plaats die een beroep in de beroepsloopbanen van arbeids-krachten inneemt. Wat het laatste betreft gelden de volgende typeringen:

$\mathrm{NM}_{\mathbf{j}}<0$ instroom- of doorstroomberoep

$\mathrm{NM}_{j}>0$ eindhalte-beroep

De waarde van de verschillende indicatoren zal overigens beinvloed worden door de werkgelegenheidsontwikkeling in het beroep en het aanbod van schoolverlaters en herintreders op het desbetreffende arbeidsmarktsegment. 
Van de indicatoren $\mathrm{TM}_{j}$ en $\mathrm{UM}_{j}$ moet op basis van empirisch onderzoek worden vastgesteld welke waarden hoog of laag genoemd kunnen worden.

De netto-mobiliteitsindicator $\left(\mathrm{NM}_{j}\right)$ kan van belang zijn voor de studieen beroepskeuzevoorlichting, ter vaststelling van de mate waarin beroepen al of niet voor schoolverlaters open staan. Voor werkgevers kan het belangrijk zijn om in het oog te houden hoe de toe- en uittredingsmobiliteit van beroepen (respectievelijk vergelijking 17 en 18) zich ontwikkelt.

Wanneer bovenstaande indicatoren kunnen worden vastgesteld voor arbeidskrachten die zijn omgeschoold, zou een indruk kunnen worden gekregen van de effectiviteit van de desbetreffende omscholing.

Momenteel is het slechts mogelijk dergelijke indicatoren te berekenen op basis van steekproeven met een beperkte omvang, zoals het OSA-panel. Het is daarom alleen mogelijk de indicatoren op een hoog aggregatieniveau te berekenen. Wanneer, zoals momenteel wordt overwogen, in de Enquête Beroeps-bevolking een retrospectieve vraag naar het op een eerder tijdstip uitgeoefende beroep wordt opgenomen, zouden deze indicatoren op een lager aggregatieniveau kunnen worden berekend. Het is echter niet realistisch te verwachten dat in dat geval een verdergaande desaggregatie dan het 2-digit niveau mogelijk is. 


\section{RELATIE ARBEIDSMARKTPROGNOSES EN -INDICATOREN}

\subsection{Arbeidsmarktindicatoren als additionele kengetallen}

De arbeidsmarktindicatoren die in deze nota besproken zijn, kunnen vrijwel allemaal fungeren als een additionele informatiebron naast de prognoses van de middellange-termijnperspectieven van opleidingen en beroepen. Dit geldt in de eerste plaats voor de indicatoren die een belangrijke monitoring-functie hebben, zoals de indicator van de actuele arbeidsmarktschaarste (paragraaf 2.1), de absorptiegraad (paragraaf 2.2), de indicator met betrekking tot de uitwijkmogelijkheden van beroepen en opleidingen (paragraaf 2.4) en de indicator van de concurrentiekracht van opleidingen (paragraaf 2.5). De indicator van de actuele arbeidsmarktschaarste kan daarbij ook fungeren als een early indicator van de realisatie van de voorspellingen van middellange-termijnprognoses.

Ook de indicator van de conjunctuurgevoeligheid van beroepen en opleidingen (paragraaf 2.3) kan naast de voorspelling van het middellangetermijnperspectief worden gepresenteerd. Hetzelfde geldt voor de indicatoren van de toe- en uittredingsmobiliteit van beroepen (paragraaf 2.6). Alleen de indicator van de (historische) vervangingsbehoefte voegt geen wezenlijke informatie toe aan de middellange-termijnprognoses.

Met name de conjunctuurgevoeligheidsindicator, de indicatoren van de uitwijkmogelijkheden en de indicator van de concurrentiekracht van opleidingen, verstrekken informatie die, in aanvulling op de informatie vanuit de middellange-termijnprognose, van belang is voor het nemen van beleids- en studiekeuzebeslissingen in een situatie van onzekerheid ten aanzien van de te verwachten ontwikkelingen op de arbeidsmarkt. Deze indicatoren zouden ook kunnen worden gebruikt om in combinatie met de middellange-termijnprognoses te komen tot een algehele typering van de arbeidsmarkt(vooruitzichten) van beroepen en opleidingen. Een eerste aanzet van deze aanpak is te vinden in De Grip, Heijke, Dekker en Groot (1987). In deze studies zijn de beroepen getypeerd op basis van midde1lange-termijnprognoses van de werkgelegenheid en de branchespreidingsindicator, terwijl bij de opleidingen de typering is gebaseerd op mid- 
dellange-termijnprognoses (het arbeidsmarktperspectief) en de beroepenspreidingsindicator.

De conjunctuurgevoeligheidsindicator voegt aan de midellange-termijnprognoses informatie toe over de mate warin de voorspelde werkgelegenheid(sontwikkeling) van een beroeps- of opleidingscategorie stabiel zal zijn of juist onderhevig zal zijn aan sterke fluctuaties.

De beide spreidingsindicatoren geven daarnaast informatie over de uitwijkmogelijkheden die men op de arbeidsmarkt heeft als men voor een bepaald beroep of opleiding kiest. Naarmate deze uitwijkmogelijkheden groter zijn, is de afhankelijkheid van de arbeidsmarktontwikkeling op de desbetreffende delen van de arbeidsmarkt kleiner.

De indicatoren met betrekking tot de kans op werk buiten de eigen sector, of op werk onder (of boven) het eigen opleidingsniveau, geven op dit punt belangrijke aanvullende informatie. Hetzelfde geldt voor de indicator van de concurrentiekracht van opleidingen.

\subsection{Integratie arbeidsmarktprognoses en -indicatoren}

Sheldon (1985) heeft een poging gedaan om de mobilititsindicatoren geheel te integreren in de prognoses van de arbeidsmarktperspectieven van de verschillende beroepen. Hij doet dit door in plaats van een exacte 'puntprognose' te geven, een 'flexibiliteitscorridor' te bepalen, waarbinnen het aanbod van een bepaalde beroepscategorie kan inspelen op de arbeidsmarkt-situatie op het desbetreffende arbeidsmarktsegment.

Sheldon gaat daarbij als volgt te werk. Eerst wordt een voorspelling gemaakt van de werkgelegenheid van een bepaald beroep. Vervolgens is een puntprognose opgesteld van het aanbod van arbeidskrachten voor het desbetreffende beroep op basis van de toestroom uit de opleidingen waarvoor het desbetreffende beroep het hoofdberoep is. Wanneer de voorspelde vraag het aanbod overtreft, zal dit niet automatisch tot een krappe arbeidsmarkt leiden, omdat er meer aanbieders zich op dit arbeidssegment kunnen aanbieden dan is voorspeld op basis van het aanbod van de opleidingscategorie waarvan beroep $i$ het hoofdberoep is. Dit additionele aanbod kan als volgt worden berekend (zie Sheldon 1985, p. 184 e.v.): 
(20)

$$
\operatorname{AAT}_{j}(1)=\sum_{k \neq k^{\prime}}\left(E_{k i} / E_{k}\right) \quad \hat{A}_{k} \quad=\sum_{k \neq k^{\prime}} \gamma_{k i} \hat{A}_{k}
$$

Waarbij $\operatorname{AAT}_{j}(1)=$ maximaal additioneel aanbod in geval van aanbodtekort van beroep $i$

$k^{\prime}=$ opleiding waarvan beroep $i$ hoofdberoep is

$\hat{A}_{k}=$ voorspelde aanbod van arbeid van opleidingscategorie $k\left(k \neq k^{\prime}\right)$

Bij deze berekening wordt, zoals we zien, gebruik gemaakt van de mogelijkheden tot passieve substitutie in het hoofdberoep van opleiding $k^{\prime}$. In deze situatie vormt de oorspronkelijke puntprognose de ondergrens van het voorspelde aanbod voor beroep $i$. Wanneer men daar het mogelijke extra aanbod bij optelt, krijgt men de bovengrens van de flexibiliteitscorridor.

Op soortgelijke wijze kan de ondergrens van de flexibiliteitscorridor worden berekend voor het geval er een aanbodoverschot voor beroep $i$ wordt verwacht:

$$
\text { (21) } V \mathrm{VOO}_{j}(2)=\left[\left(E_{k^{\prime}}-E_{k^{\prime} j}\right) / E_{k}\right] \hat{A}_{k}
$$

Waarbij: $\mathrm{VAO}_{\mathbf{j}}=$ maximaal vertrekkend aanbod in geval van aanbodoverschot beroep $i$

Sheldons aanpak heeft als belangrijk nadeel dat verondersteld wordt dat een beroep voor een bepaalde opleiding het hoofdberoep is. Zoals gezegd is dit in veel gevallen een niet terechte veronderstelling. We kunnen deze veronderstelling laten vallen, door eerst een puntprognose van het verwachte aanbod van arbeid van beroep $i$ op te stellen, op basis van de huidige aandelen van de verschillende opleidingscategorieën in de werkgelegenheid in beroep $i$. Voor zover er bij een vergelijking van deze aanbodvoorspelling met de vraagprognose van beroep $i$ sprake is van een aanbodtekort, zou het potentiële additionele aanbod als volgt kunnen worden berekend: 


$$
\operatorname{AAT}_{i}(2)=\sum_{k=1}^{K}\left[\left(1-Y_{k i}\right) \hat{A}_{k}\right]
$$

Waarbij: $\gamma_{k i}=$ aandeel in totaal aantal arbeidskrachten met opleiding $k$ Op deze manier kan de bovengrens van de flexibiliteitscorridor worden berekend. Wanneer we een soortgelijke aanpak volgen in een situatie van een aanbodoverschot, zoals berekend in vergelijking (21), is het vertrekkende aanbod in feite al opgenomen in de puntprognose zelf. Immers, verondersteld is dat van ieder beroep de huidige aandelen van de verschillende opleidingscategorieën in de werkgelegenheid in dat beroep geprojecteerd kunnen worden op het toekomstige aanbod van arbeid voor dit beroep.

De ondergrens van de flexibilteitscorridor in de voorspelling van een bepaald beroep, is van belang voor het bepalen van het uitwijkpotentieel in een situatie van een aanbodoverschot. Deze zou in dit geval kunnen worden bepaald door de berekende toetredingsmobiliteit tot de arbeidsmarktsegmenten die gekenmerkt worden door een aanbodtekort, naar evenredigheid te ontlenen aan de deelmarkten waarvoor een aanbodoverschot is berekend. De tekorten elders op de arbeidsmarkt $\left(\hat{V}_{j "}-\hat{A}_{j "}\right)$ bepalen dan de uitwijkmogelijkheden in een overschotberoep:

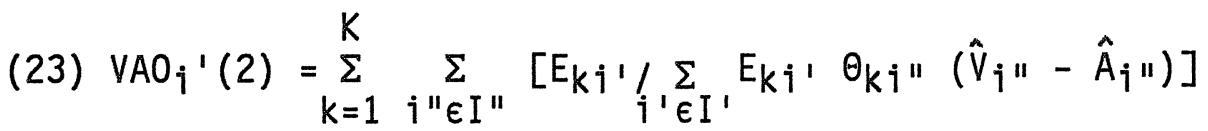

Waarbij: $j^{\prime}=$ beroep waarbij in eerste instantie aanbodoverschot wordt voorspeld

$i "=$ beroep waarvan in eerste instantie aanbodtekort wordt voorspeld

$\theta_{k j "}=$ aandeel van werkenden in beroep $i$ " met opleiding $k$

$\hat{V}_{i \prime \prime}=$ voorspelde vraag naar arbeid in beroep $i "$

$\hat{A}_{i}^{\prime \prime}=$ voorspeld aanbod van arbeid in beroep $i "$

In deze vergelijking worden de additionele instroommogelijkheden in de tekortberoepen verdeeld over de verschillende opleidingscategorieën naar rato van de opleidingsaandelen in het desbetreffende beroep:

$\theta_{k i} "\left(\hat{V}_{j "}-\hat{A}_{j "}\right)$. Deze additionele instroommogelijkheden worden vervolgens gerantsoeneerd over de verschillende overschotberoepen naar rato van het aantal werkenden in het desbetreffende beroep met opleiding $k$ 
ten opzichte van het totaal aantal werkenden met opleiding $k$ in de overschotberoepen: $E_{k i}{ }^{\prime} / \sum_{\prime^{\prime} \in I^{\prime}} E_{k i}{ }^{\prime}$

Ten opzichte van de aanpak van Sheldon heeft deze berekeningswijze het voordeel dat de voorspelde flexibiliteit op de verschillende beroepsdeelmarkten een consistent totalbeeld oplevert. Dit geldt echter alleen voor zover er sprake is van een macro-economisch aanbodoverschot. Voor zover er een macro-economisch aanbodtekort wordt verwacht, zou het totaalbeeld consistent kunnen worden gemaakt door het potentiële additionele aanbod in de tekortsectoren te rantsoeneren.

Bovenstaande aanpak zou ook gevolgd kunnen worden voor het flexibiliseren van de prognoses van de arbeidsmarktsituatie voor verschillende opleidingscategorieën. Voor opleidingen waarvoor een aanbodoverschot wordt verwacht kan het flexibiliteitspotentieel als volgt worden bepaald:

$$
\operatorname{AVO}_{k}=\sum_{i " \in I "} \theta_{k i}\left(\hat{V}_{i}-\hat{A}_{i}\right)
$$
Waarbij: $A \mathrm{OVO}_{k}=\underset{\text { mogelijke aanvullende vraag in geval van aanbodover }-}{ }$

Van opleidingscategorieën waarvoor in eerste instantie een aanbodtekort bestaat bedraagt het flexibiliseringspotentieel:

$$
\text { DVT }_{K^{\prime \prime}}=\sum_{j " \in I "}\left[\min \left(E_{K^{\prime \prime}} \| \sum_{K^{\prime} \in K^{\prime}} E_{K^{\prime}} i^{\prime \prime}\right]\right.
$$

Waarbij: DVT $_{K^{\prime \prime}}=$ maximaal mogelijke daling vraag in geval van aanbodtekort van opleiding $k "$

$K^{\prime}$ = opleidingen waarvoor aanbodoverschot bestaat.

Verondersteld wordt dan dat de verschillende opleidingscategorieën de in eerste instantie voorspelde tekorten in beroep $i$ ", naar evenredigheid van hun berekende aandeel in de werkgelegenheid in beroep $i$ " zullen aanvullen. 


\section{BESLUIT}

Zoals in de inleiding werd opgemerkt, beoogt deze nota een eerste inventarisatie te geven van de arbeidsmarktindicatoren die, naast de middellange-termijnprognoses, aanvullende informatie geven met betrekking tot de arbeidsmarkt(ontwikkeling) voor beroepen en opleidingen. Daarbij is telkens aangegeven voor welke doeleinden deze informatie van belang zou kunnen zijn. Tenslotte is in hoofdstuk 3 aangegeven op welke wijze de informatie kan worden gecombineerd met de voorspellingen van de arbeidsmarktperspectieven. De meest eenvoudige aanpak daarbij is het geven van een algehele typering van beroepen en opleidingen die uit beiden componenten bestaat, dat wil zeggen: prognoses naast aanvullende indicatoren (zie paragraaf 3.1). Met betrekking tot het beroepsmobiliteitspotentieel van het arbeidsaanbod is het echter mogelijk de aanwezige flexibiliteit te integreren in de prognoses van de arbeidsmarktperspectieven van beroepen en opleidingen (paragraaf 3.2 ). Wat het laatste betreft is het noodzakelijk een nadere analyse te verrichten van de mogelijkheid om op basis van bijvoorbeeld een clusteranalyse, de arbeidsmarktsegmenten waarvoor prognoses worden opgesteld zodanig vast te stellen, dat de arbeidsmarkt-flexibiliteit zich voor het overgrote deel afspeelt binnen deze arbeids-marktsegmenten (zie De Grip, Groot en Heijke 1987 en Teulings en Vriend 1987).

Schema 4.1 geeft een overzicht van de verschillende soorten arbeidsmarkt-indicatoren die in deze nota zijn besproken. Achtereenvolgens wordt aangegeven of:

- een indicator een monitoringfunctie zou kunnen vervullen;

- er sprake is van aanvullende informatie ten opzichte van middellange-termijnprognoses van de arbeidsmarktperspectieven, die kan worden opgenomen in een algehele typering van beroepen en opleidingen;

- een integratie met de middellange-termijnprognoses mogelijk is;

- voor welke doeleinden de indicator van belang kan zijn. 
Schema 4.1: Overzicht besproken arbeidsmarktindicatoren

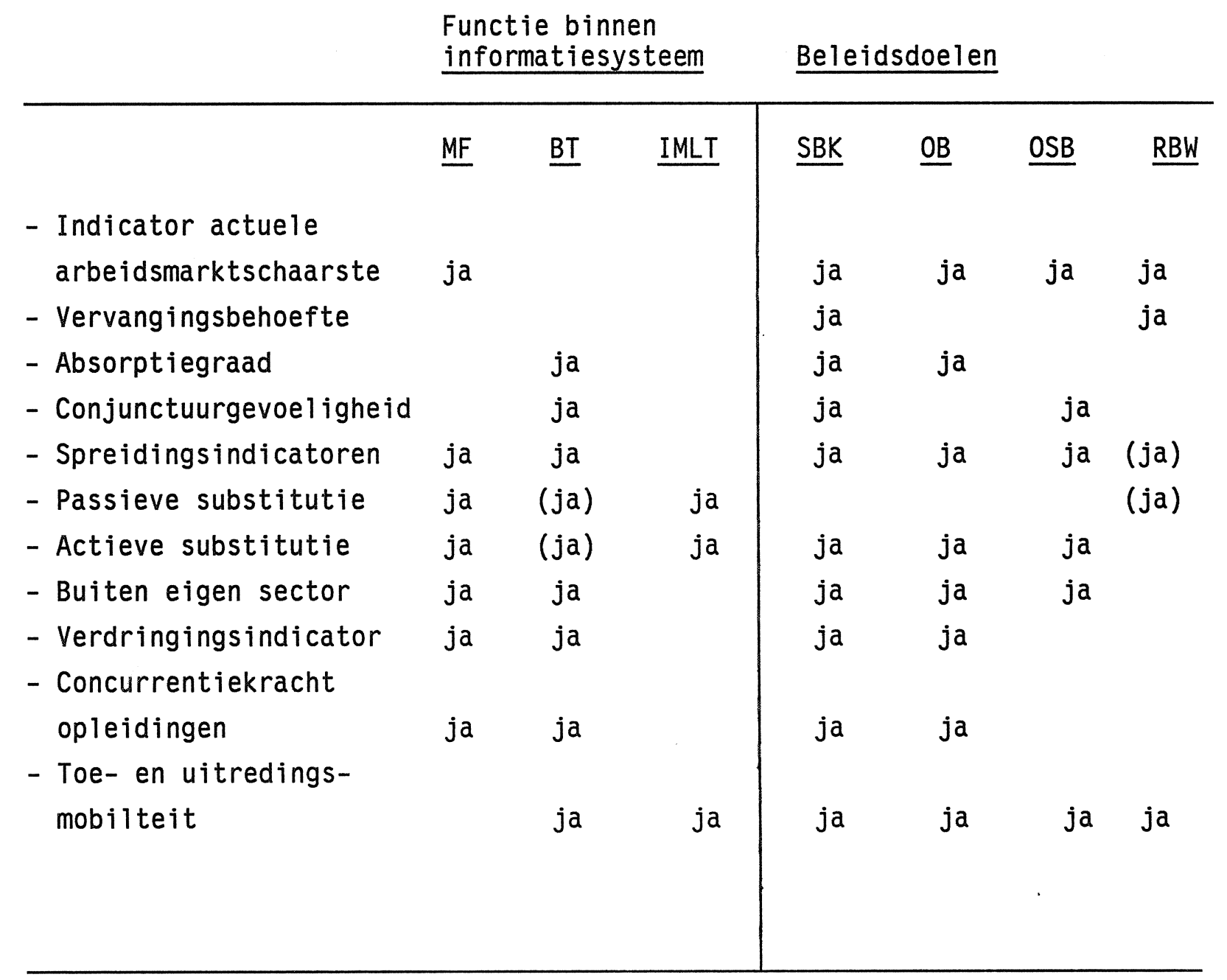

Verklaring afkortingen:

MF = Monitoring functie

BT = Bruikbaar in algehele typering

IMLT = Integratie met middellange-termijnprognoses

SBK = studie- en beroepskeuzevoorlichting

$O B=$ Onderwijsbeleid

OSB = Omscholingsbeleid

RBW = Recruteringsbeleid werkgevers 


\section{LITERATUUR}

Bergeijk, C. van, A. de Grip (1986), Bestaan en ontwikkeling van interne arbeidsmarkten in Nederland, in: Sociaal Maandblad Arbeid, p. 437451.

Dekker, R.J.P., A. de Grip, J.A.M. Heijke (1988), Een verklaring van de beroepenstructuur van bedrijfstakken, ROA-W-1988/2, Maastricht.

Grip, A. de (1987), Onderwijs en Arbeidsmarkt: Scholingsdiscrepanties, VUuitgeverij, Amsterdam.

Grip, A. de, J.A.M. Heijke, L.A. Vos (1987), Inventariserend onderzoek arbeidsmarktmodule I-SEE project, ROA-R-1987/1, Maastricht.

Grip, A. de, J.A.M Heijke, R.J.P. Dekker, L.F.M. Groot, L.A. Vos (1987), De arbeidsmarktperspectieven van studierichtingen in het wetenschappelijk onderwijs 1992; Arbeidsmarktmodule I-SEE project, ROA-R-1987/3, Maastricht.

Grip, A. de, J.A.M. Heijke, R.J.P. Dekker, L.F.M. Groot, (1987) De arbeidsmarkt naar beroep in 1992 en de positie van academici daarbinnen, ROA-W-1987/1, Maastricht.

Grip, A. de, L.F.M. Groot, J.A.M. Heijke (1987), Clustering occupational classes by educational structure, ROA-W-1987/2E, Maastricht.

Haanstra, F., J.K. Koppen, J.D. Oostwoud Wijdenes, (1987), De samenhang onderwijs-beroepspraktijk in de sector van de beeldende kunsten, Ministerie van Onderwijs \& Wetenschappen, Staatsdrukkerij, 'sGravenhage.

Heijke, J.A.M., Het Researchcentrum voor Onderwijs en Arbeidsmarkt, ROA-R-1986/1, Maastricht 1986.

Hoof, J.J. van, J. Dronkers (1980), Onderwijs en arbeidsmarkt, Sociologische monografieën, Van Loghum Slaterus, Deventer.

Huijgen, F., B.J.P. Riesewijk, G.J.M. Conen (1983), De kwalitatieve structuur van de werkgelegenheid in Nederland-Bevolking in loondienst en functie-niveaustructuren in de periode 1960-1977, NPA0, 'sGravenhage.

Jonker, J.K. (1987), Op weg naar een nieuwe CBS-beroepenclassificatie, discussienota, CBS, Voorburg.

Paridon, W.C.G.M. van, (1987), De arbeidsmarktindicator, in: Management Berichten, jrg. 13, nr. 3, p. 42-46.

Sheldon, G. (1985), Die berufliche und Geographische Flexibiliät, Institut fur Arbeitsmarkt und Berufsforschung der Bundesanstalt fur Arbeit, Beitrage $A B$ 92, Nurnberg.

Teulings, C., N. Vriend (1987), Een empirische afbakening van beroepsdeelmarkten, SEO, Amsterdam.

Warnken, J. (1986), Zur Entwicklung der "internen" Anpassungsfähigkeit der Berufe bis zum Jahre 2000. Projektionen unter den Annahmen der Wachstumszenaren der Prgnos-Studie, Mitteilungen aus der Arbeitsmarkt- unde Berufsforschung, no. 1, p 119-133. 